5 Harland WA, Gilbert JD, Steel G, Brooks CJW. Lipids of human atheroma. Part 5. The occurrence of a new group of polar sterol esters in various stages of human atherosclerosis. Atherosclerosis 1971;13:239-46.

6 Dormandy JA, Hoare E, Khattab AH, Arrowsmith DE, Dormandy TL. Prognostic significance of rheological and biochemical findings in patients with intermitrent claudication. BrMed 7 1973:iv:581-3.

7 Goto Y. Lipid peroxides as a cause of vascular disease. In: Yagi K, ed. Lipid peroxides in biologv and medicine. New York: Academic Press Inc, 1982: 295-303.

8 Loeper J, Emerit J, Goy J, Bedu O, Loeper J. Lipid peroxidation during human atherosclerosis. IRCS fournal of Medical Science 1983;11:1034-5,

9 Yagi K. Increased serum lipid peroxides initiate atherogenesis. Bioassays 1984;1:58-60

10 Yagi K. Assay for serum lipid peroxide level and its clinical significance. In: Yagi $\mathrm{K}$, ed. Lipid peroxides in biology and medicine. New York: Academic Press, 1982:223-42.

11 Sato Y, Hotta N, Sakamoto N, Matsuoka S, Ohishi N, Yagi K. Lipid peroxide level in plasma of diabetic patients. Biochem Med 1979;21:104-7.

12 Uysal $\mathrm{M}$, Buler $\mathrm{H}$, Sener $\mathrm{D}, \mathrm{Oz} \mathrm{H}$. Lipid peroxidation in patients with essential hypertension. Int 7 Clin Pharmacol Res 1986;24:474-6.

13 Loeper J, Goy J, Bedu O, Rozensztajn L. Lipid peroxidation and protective enzymes during the course of myocardial infarction. Agents Actions 1987;22: $340-2$.

14 Greenhalgh RM, Lewis B, Rosengarten DS, Calnan JS, Mervart I, Martin P. Serum lipids and lipoproteins in peripheral vascular disease. Lancet 1971;ii:947-50.

15 Yagi K, Ohkawa H, Ohishi N, Yamashita M, Nakashima T. Lesion of aortic intima caused by intravenous administration of linoleic acid hydroperoxide. 7 Appl Biochem 1981;3:58-65.

16 Szczeklik A, Gryglewski RJ, Domagala B, Dworski R, Basista M. Dietary supplementation with vitamin $\mathrm{E}$ in hyperlipoproteinaemias: effects on supplementation with vitamin $\mathrm{E}$ in hyperlipoproteinaemias: effects on
plasma lipid peroxides, antioxidant activity, prostacyclin generation and plasma lipid peroxides, antioxidant activity, prostacycin

17 Steinbrecher UP, Parthasarathy S, Leake DS, Witztum JL, Steinberg D. Modification of low density lipoprotein by endothelial cells involves lipid peroxidation and degradation of low density lipoprotein phospholipids. Proc Natl Acad Sci USA 1984;81:3883-7.

18 Cathcart MK, Morel DW, Chisholm GM. Monocytes and neutrophils oxidize low density lipoprotein making it crtotoxic. I Leukocyle Biol 1985;38 $3+1-50$
19 Halliwell B, Gutteridge JM. Free radicals in biology and medicine. Oxford: Clarendon Press, 1985.

20 Therasse J, Lemonnier F. Determination of plasma lipoperoxidases by high performance liquid chromatography. $\mathcal{A}$ Chromalogr 1987:413:237-41.

21 Nishigaki I, Hagihara M, Tsunekawa H, Maseki M, Yagi K. Lipid peroxide levels of serum lipoprotein fractions of diabetic patients. Biochem Med $1981 ; 2: 373-8$

22 Szczeklik A, Gryglewski RJ, Domagala B, et al. Serum lipoproteins, lipid peroxides and prostacyclin biosynthesis in patients with coronary heart peroxides and prostacyclin biosynthesis

23 Hinsbergh VWM. Biologic generation and metabolic effects of oxidized lipoproteins. Agents Actions 1987;22:349-50.

24 Fogelman AM, Schechter I, Seager J, Hokom M, Child JS, Edwards PA. Malondialdehyde alteration of low density lipoproteins leads to cholesterol ester accumulation in human monocyte-macrophages. Proc Natl Acad Sci USA. 1980;77:2214-8.

25 Mitchinson MJ, Ball RY. Macrophages and atherogenesis. Lancet 1987;ii: $146-8$

26 Evensen SA, Galdal KJ, Nilsen E. LDL-induced cytotoxicity and its inhibition by anti-oxidant treatment in cultured human endothelial cells and fibroblasts. Atherosclerosis 1983;49:23-30.

27 Szczeklik A, Gryglewski RJ. Low density lipoproteins (LDL) are carriers for lipid peroxides and inhibit prostacyclin $\left(\mathrm{PGI}_{2}\right)$ biosynthesis in arteries. Artery 1980;7:488-95.

28 Gray E, Barrowcliffe TW. Inhibition of antithrombin III by lipid peroxides. Thromb Res 1985;37:241-50.

29 Barrowcliffe TW, Gutteridge JM, Gray E. Oxygen radicals, lipid peroxidation and the coagulation system. Agents Actions 1987;22:347-8.

30 Klimov AN, Kozhemakin LA, Pleskov VM, Andreeva LI Antioxidant effect of high-density lipoproteins in peroxidation of low-density lipoproteins. Byulleten Eksperimental noi Biologii i Meditsiny 1987;103:552-5.

31 Ross R. The pathogenesis of atherosclerosis - an update. $N$ Engl f Med 1986;314:488-500

32 Heinle $\mathrm{H}$, Liebich $\mathrm{H}$. The influence of diet-induced hypercholesterolaemia on the degree of oxidation of glutathione in rabbit aorta. Atherosclerosis 1980;37:637-40

33 Szamosi T, Gara I, Venekei I, Javor A, Ceskel R, Knoll J. Serum lipids, lipid peroxides and the care of children with high risk atherosclerotic family historv. Atherosclerosis 1987;68:111-5.

Accepted 17 November 1988

\title{
Short term effect of captopril on microalbuminuria induced by exercise in normotensive diabetics
}

Cattedra di Patologia Speciale Medica, University of Brescia, II Divisione Medicina, Spedali Civili, 25124

Brescia, Italy Giuseppe Romanelli, MD, researcher

Andrea Giustina, MD, attending physician

Antonino Cimino, MD, physician

Umberto Valentini, MD, registrar

Gianni Giustina, MD,

professor of medicine

Cattedra di Clinica Medica e Terapia Medica,

University of Brescia, Brescia, Italy

Enrico Agabiti-Rosei, MD, associate professor of medical therapeutics

Giulio Muiesan, MD, professor of medicine

Correspondence to: $\mathrm{Dr}$ Romanelli.

Giuseppe Romanelli, Andrea Giustina, Antonino Cimino, Umberto Valentini, Enrico Agabiti-Rosei, Giulio Muiesan, Gianni Giustina

\section{Abstract}

Objective-To investigate whether captopril has any effect on microalbuminuria induced by exercise in normotensive diabetic patients with early stage nephropathy.

rial.

Setting-Outpatient department.

Patients -22 diabetics with stage II nephropathy (urinary albumin excretion rate $<20 \mu \mathrm{g} / \mathrm{min} ; 15$ with type I diabetes and seven with type II), 32 patients with stage III nephropathy (urinary albumin excretion rate $20-200 \mu \mathrm{g} / \mathrm{min} ; 14$ with type I diabetes and 18 with type II), and 10 normal subjects.

Interventions-Four exercise tests on a cycle ergometer: the first two under basal conditions and the third and fourth after subjects had received captopril (two $25 \mathrm{mg}$ doses in 24 hours) or placebo (two tablets in 24 hours).

End Point-Exercised until $\mathbf{9 0 \%}$ of maximum heart rate achieved.

Measurements and main results-Mean urinary excretion one hour after the first two exercise tests was $21 \mu \mathrm{g} / \mathrm{min}$ in normal subjects, $101 \mu \mathrm{g} / \mathrm{min}$ in diabetic patients with stage II nephropathy, and $333 \mu \mathrm{g} / \mathrm{min}$ in those with stage III nephropathy. Similar results were obtained after placebo. After captopril the urinary excretion rate one hour after exercise was significantly decreased in diabetics with stage II $(36 \mu \mathrm{g} / \mathrm{min})$ and stage III $(107 \mu \mathrm{g} / \mathrm{min})$ disease compared with placebo but not in normal subjects. Systolic and diastolic pressures were similar in the three groups after placebo and captopril had been given.
Conclusions-Captopril significantly reduces microalbuminuria induced by exercise in normotensive diabetics without affecting systemic blood pressure. Captopril may reduce renal intracapillary pressure.

\section{Introduction}

Diabetic nephropathy is one of the main causes of increased morbidity and mortality in diabetic patients. ${ }^{2}$ Even before the onset of the clinical syndrome of diabetic nephropathy, which is characterised by persistent proteinuria, progressive decline in glomerular filtration rate, and increased arterial blood pressure (stage IV of diabetic nephropathy), there is a "silent" period of variable duration during which diabetic patients have only microalbuminuria - that is, their mean urinary albumin excretion rate is significantly higher $(20-200 \mu \mathrm{g} / \mathrm{min})$ than that in normal subjects but is detectable only by radioimmunological methods.

Physical exercise can induce an abnormal increase in the urinary albumin excretion rate in diabetics with microalbuminuria while resting (stage III) ${ }^{4}$; it can also induce microalbuminuria in diabetics who do not excrete protein while resting (stage II) and therefore can disclose an early stage of renal disease. Recent studies have shown that chronic inhibition of angiotensin converting enzyme may reduce baseline microalbuminuria in normotensive diabetic patients; such inhibition could be effective in slowing the progression of diabetic nephropathy. The aim of our study was to investigate the short term effect of the angiotensin converting enzyme inhibitor captopril on micro- 
albuminuria induced by exercise in normotensive patients who had type I and type II diabetes with or without microalbuminuria at rest.

\section{Subjects and methods}

The patients in this study were selected from 500 diabetic patients according to the following criteria: age 15-55; stable body mass index (weight (height) $<25 \mathrm{~kg} / \mathrm{m}^{2}$ ); supine blood pressure $<160 / 95 \mathrm{~mm} \mathrm{Hg}$; urinary albumin excretion rate $0-200 \mu \mathrm{g} / \mathrm{min}$ in samples assessed weekly during the three months before the study; and no cardiovascular, hepatic, or systemic disease. The patients were not taking any drug other than for treatment of their diabetes. Owing to the high variability of urinary albumin excretion rate in individual patients only patients who had variations within $15 \%$ of their average rate, measured by weekly assays in the three months before the study, were included. ${ }^{6}$

Fifty four patients were admitted to the study and were divided into two groups according to urinary albumin excretion rate at rest. Twenty two had a urinary albumin excretion rate of $<20 \mu \mathrm{g} / \mathrm{min}$ (stage II diabetic nephropathy); they comprised 12 men and 10 womtn, age range $16-44 ; 15$ had type I diabetes and seven type II. Thirty two patients had a urinary albumin excretion rate of $20-200 \mu \mathrm{g} / \mathrm{min}$ (stage III diabetic nephropathy); they comprised 20 men and 12 women, age range $18-50 ; 14$ had type I diabetes and 18 type II. Ten normal subjects (six men, four women, age range 18-40) served as controls.

All patients gave their informed consent to the study. All patients with type I diabetes received conventional insulin treatment (mean dose 49 (SD 16) U/day); patients with type II diabetes were treated with oral hypoglycaemic agents and diet. Three months before and during the study the patients and controls were instructed to follow a diet of about $8.6 \mathrm{MJ} /$ day comprising 50\% carbohydrates, 35\% lipids, and $15 \%$ proteins with no restriction in sodium intake.

\section{STUDY PROTOCOL AND METHODS}

Patients performed four physical exercise tests at intervals of 72 hours. For each test they attended the outpatient department at 8 am with a 24 hour urine sample collected the previous day for measurement of urinary albumin excretion rate and creatinine concentration. A blood sample was taken for routine haematochemical tests and urine was collected. Patients remained recumbent for one hour and drank $500 \mathrm{ml}$ of water. At 9 am a blood sample was taken for measurement of plasma renin activity and plasma aldosterone concentration and an exercise test on a cycle ergometer was performed. Workload was

TABLE I-Clinical characteristics of subjects grouped according to baseline urinary albumin excretion rate. Values are means $(S D)$

\begin{tabular}{|c|c|c|c|}
\hline & $\begin{array}{l}\text { Normal subjects } \\
\qquad(\mathrm{n}=10)\end{array}$ & $\begin{array}{c}\text { Diabetic patients } \\
\text { with stage II } \\
\text { nephropathy } \\
(\mathrm{n}=22)\end{array}$ & $\begin{array}{c}\text { Diabetic patients } \\
\text { with stage III } \\
\text { nephropathyt } \\
(\mathrm{n}=32)\end{array}$ \\
\hline Age (vears) & $30(7)$ & $35(8)$ & $40(9)$ \\
\hline Sex & $6 \mathrm{M}, 4 \mathrm{~F}$ & $12 \mathrm{M}, 10 \mathrm{~F}$ & $20 \mathrm{M}, 12 \mathrm{~F}$ \\
\hline Body mass index $(\mathrm{kg} / \mathrm{m})$ & $22(4)$ & $23(3)$ & $23(4)$ \\
\hline Systolic blood pressure $(\mathrm{mm} \mathrm{Hg})$ & $128(18)$ & $135(16)$ & $141(20)$ \\
\hline Diastolic blood pressure $(\mathrm{mm} \mathrm{Hg})$ & $83(9)$ & $86(8)$ & $90(9)$ \\
\hline Heart rate (beats $/ \mathrm{min})$ & $79(9)$ & $82(8)$ & $77(6)$ \\
\hline Plasma renin activity (nmol///h) & $0.53(0.11)$ & $0.56(0 \cdot 17)$ & $0.42(0 \cdot 14)$ \\
\hline Serum aldosterone $(\mathrm{pmol} / \mathrm{l})$ & $233(47)$ & $214(61)$ & $216(58)$ \\
\hline \multicolumn{4}{|l|}{ No of patients with: } \\
\hline Insulin dependent diabetes & & 15 & 14 \\
\hline Non-insulin dependent diabetes & & 7 & 18 \\
\hline Duration of diabetes (months) & & $63(12)$ & $87(18)$ \\
\hline Haemoglobin $A_{1}(\%)$ & $4 \cdot 1(0.9)$ & $7 \cdot 8(1 \cdot 3)$ & $8 \cdot 1(1 \cdot 2)$ \\
\hline Serum creatinine $(\mu \mathrm{mol} / \mathrm{l})$ & $71(13) \mu \mathrm{mol} / \mathrm{l}$ & 79 (18) $\mu \mathrm{mol} / 1$ & $83(28) \mu \mathrm{mol} / \mathrm{l}$ \\
\hline Creatinine clearance $(\mathrm{ml} / \mathrm{min})$ & $129(24)$ & $134(19)$ & $121(28)$ \\
\hline
\end{tabular}

increased by $30 \mathrm{~W}$ every two minutes until $90 \%$ of the theoretical maximal heart rate was achieved. This workload was maintained for five minutes. During the test blood pressure was measured every two minutes and after the test another blood sample was taken for measurement of plasma renin activity and aldosterone concentration.

When heart rate and blood pressure had returned to basal values (after 10 to 20 minutes) the patients voided and a sample of urine was taken for assay of albumin concentration. The patients remained recumbent for one hour and drank $500 \mathrm{ml}$ water. At the end of this period they voided again and total diuresis was calculated and samples for measurement of albumin and creatinine concentrations were taken. Blood glucose concentrations were monitored at rest, at the end of exercise, and 30,60, and 90 minutes after the end of exercise. Patients were then asked to collect their urine until 8 am the next day for albumin and creatinine assays. The patients were always followed up by the same investigator.

The first two physical exercise tests were performed under basal conditions to evaluate the reproducibility of the duration of exercise and of the urinary albumin excretion rate after exercise. In all of the patients the difference in albumin excretion between the first two exercise tests was not greater than $15 \%$. The third and fourth exercise tests were performed two hours after the last dose of captopril (two $25 \mathrm{mg}$ doses in 24 hours) or placebo (two tablets in 24 hours) given according to a randomisation schedule in a double blind crossover design.

\section{ASSAYS}

Commercial radioimmunoassay kits were used to measure albumin concentration (Sclavo, Siena, Italy; intra-assay coefficient of variation $5 \%$, interassay coefficient of variation $6 \cdot 5 \%$, sensitivity limit $0 \cdot 1 \mathrm{mg} / \mathrm{l}$ ), plasma renin activity (Sclavo, Siena, Italy), and plasma aldosterone concentration (Sorin, Saluggia, Italy). Haemoglobin $A_{l c}$ concentration was measured by a chromatographic method (Biodata, Roma, Italy; normal range $3-6 \%$ ). Urinary sodium, potassium, and creatinine concentrations were measured with flame photometry. Plasma glucose concentration was determined by the glucose oxidase method (Beckman II glucose analyser).

\section{STATISTICAL ANALYSIS}

Analyses of variance and covariance were used to compare percentage increases and absolute values of exercise induced albuminuria and of systolic and diastolic blood pressures within the same group in the different experimental conditions and among the three groups in the same experimental conditions. ${ }^{7}$ Linear regression was used to assess the relation between exercise induced albuminuria and systolic blood pressure. The standard paired or unpaired $t$ test was used for other calculations. All calculations were performed with the biomedical data programs (BMDP) package on an IBM AT computer. All data are expressed as means (standard deviation), and all reported $p$ values are two sided.

\section{Results}

Table I shows the clinical data on the subjects studied. Diabetic patients with stage III nephropathy had a longer duration of the disease and were older than those with stage II nephropathy. Metabolic control was equally good in both groups. All other variables were similar in the three groups.

\section{EXERCISE TESTS UNDER BASAL CONDITIONS}

No significant difference among the three groups 
was observed in blood pressure initially and at the end of the first two exercise tests (table II). At the end of these exercise tests the mean urinary albumin excretion rate was increased significantly in each group (normal subjects $t=15.21, \mathrm{df}=9, \mathrm{p}<0.001)$; patients with stage II nephropathy $t=17 \cdot 49, \mathrm{df}=21, \mathrm{p}<0.001$; and patients with stage III nephropathy $t=39, \mathrm{df}=31$, $\mathrm{p}<0.001$ ) (table II). The increase in urinary albumin excretion rate, expressed as percentage variation, was significantly greater in the diabetic patients with stage II nephropathy than in the normal subjects $(154(54) \%$ $v 82(27) \% ; t=4, \mathrm{df}=30, \mathrm{p}<0.001)$ and in the diabetics with stage III disease than in those with stage II disease $(250(35) \%$ v 154(54)\%; $t=7.94, \mathrm{df}=52, \mathrm{p}<0.001)$. Similar increases were seen in the urinary albumin excretion rate one hour after exercise (normal subjects $169(82) \%$, patients with stage II disease 505(101)\%, and patients with stage III disease $607(106) \%)$. The urinary albumin excretion rate 24 hours after the exercise tests was similar to the baseline rate in all groups. In normal subjects no correlation between the urinary albumin excretion rate one hour after exercise and increases in blood pressure induced by exercise was found, but such a correlation was present in diabetics with stage II and stage III nephropathy $(\mathrm{r}=0.544, \mathrm{p}<0.01$, and $\mathrm{r}=0.744, \mathrm{p}<0.001$, respectively).

Plasma renin activity after exercise was $1 \cdot 16(0 \cdot 28)$ $\mathrm{nmol} / \mathrm{l} / \mathrm{h}$ in the normal subjects, $1 \cdot 22(0 \cdot 28) \mathrm{nmol} / \mathrm{l} / \mathrm{h}$ in patients with stage II nephropathy, and 0.83 $(0 \cdot 28) \mathrm{nmol} / \mathrm{l} / \mathrm{h}$ in patients with stage III nephropathy. Plasma aldosterone concentration was 405 (50) pmol/1 in the normal subjects, $416(119) \mathrm{pmol} / \mathrm{l}$ in patients with stage II disease, and 472 (133) pmol// in patients with stage III disease. All these increases were significant $(p<0.001)$ in all groups but not among groups.

\section{EXERCISE TESTS AFTER CAPTOPRIL AND PLACEBO}

The third exercise test was performed by 31 subjects who had been given captopril and 33 subjects who had been given placebo. Compared with values seen under basal conditions, urinary albumin excretion rate and blood pressure before exercise were slightly lower in each group, although not significantly, after captopril compared with placebo, and heart rate was slightly but not significantly increased in all groups. The increase in blood pressure with exercise was slightly lower only after captopril (table II).

Immediately after exercise the urinary albumin excretion rate was significantly lower with captopril compared with placebo when expressed both as an absolute value $(56(27) \mu \mathrm{g} / \mathrm{min} v 115(65) \mu \mathrm{g} / \mathrm{min}$ for all the diabetics; $t=10.62, \mathrm{df}=53, \mathrm{p}<0.001)$ and as percentage increase from the baseline value $(76(41) \%$ r $211(64) \%$ for all the diabetics $(t=13 \cdot 43, \mathrm{df}=53$, $\mathrm{p}<0.001)$; percentage increase after captopril in patients with stage II nephropathy $93(52) \%(t=5 \cdot 45$, $\mathrm{df}=21, \mathrm{p}<0.001)$ and in those with stage III disease $64(26) \%(t=35 \cdot 38, \mathrm{df}=31, \mathrm{p}<0 \cdot 001))$. This decrease was significantly related to basal plasma renin activity in patients with stage II and stage III nephropathy $(\mathrm{r}=0.62, \mathrm{p}<0.01$ and $\mathrm{r}=0.64, \mathrm{p}<0.01$, respectively).

One hour after exercise the urinary albumin excretion rate was further decreased both in the whole group of diabetic patients $(78(39) \mathrm{\mu g} / \mathrm{min}$ after captopril $v$ $239(121) \mu \mathrm{g} / \mathrm{min}$ after placebo, $t=13 \cdot 25, \mathrm{df}=53$, $\mathrm{p}<0.001$; percentage increase $150(65) \%$ v 590(152)\%, $t=23, \mathrm{df}=53, \mathrm{p}<0.001)$ and, as a percentage increase, in those with stage II nephropathy $(143(65) \%, t=$ $11.08, \mathrm{df}=21, \mathrm{p}<0.001)$ and stage III disease $(154(66) \%, t=23 \cdot 58, \mathrm{df}=31, \mathrm{p}<0 \cdot 001)$. Table II shows the absolute values. After 24 hours the urinary albumin excretion rate was similar to baseline values in all groups. In the normal subjects the increase in the urinary albumin excretion rate immediately after and one hour after exercise was similar after captopril and after placebo (table II).

Analysis of variance and covariance showed a significant decrease in the urinary albumin excretion rate after captopril when either basal urinary albumin excretion rate or systolic blood pressure during peak exercise were used as covariates $(F=24 \cdot 66, \mathrm{df}=1,60$, $\mathrm{p}<0.001$, and $\mathrm{F}=21.46, \mathrm{df}=1,60, \mathrm{p}<0.001$, respectively). No correlation was seen between urinary albumin excretion rate one hour after exercise and increases in blood pressure induced by exercise in patients with either stage II or stage III nephropathy who had been given captopril (fig).

Plasma renin activity was significantly higher $(\mathrm{p}<0.01)$ in all groups after captopril both before and at the end of exercise when compared with values after placebo and under basal conditions. No significant difference in increases in plasma renin activity was seen among the three groups. Plasma aldosterone concentrations were similar to those seen after no treatment. After placebo all values of variables were similar to those recorded after no treatment.

\section{Discussion}

Our results show that short term administration of the angiotensin converting enzyme inhibitor captopril is associated with a reduction in albumin excretion after exercise in normotensive patients who have type I and type II diabetes and whose renal function is normal, whether these patients have normal albu-

TABLE II-Mean (SD) blood pressure and urinary albumin excretion rate before and after exercise tests in normal subjects and diabetic patients basally (tzo tests done) and after captopril or placebo given in random order

\begin{tabular}{|c|c|c|c|c|c|c|c|c|c|}
\hline & \multicolumn{3}{|c|}{$\begin{array}{l}\text { Normal subjects } \\
\qquad(\mathrm{n}=10)\end{array}$} & \multicolumn{3}{|c|}{$\begin{array}{l}\text { Diabetic patients } \\
\text { with stage II nephropathy } \\
\qquad(\mathbf{n}=22)\end{array}$} & \multicolumn{3}{|c|}{$\begin{array}{l}\text { Diabetic patients } \\
\text { with stage III nephropathy } \\
\qquad(\mathbf{n}=32)\end{array}$} \\
\hline & $\begin{array}{c}\text { No } \\
\text { treatment }\end{array}$ & $\begin{array}{l}\text { After } \\
\text { captopril }\end{array}$ & $\begin{array}{c}\text { After } \\
\text { placebo }\end{array}$ & $\begin{array}{c}\text { No } \\
\text { treatment }\end{array}$ & $\begin{array}{c}\text { After } \\
\text { Captopril }\end{array}$ & $\begin{array}{c}\text { After } \\
\text { placebo }\end{array}$ & $\begin{array}{c}\text { No } \\
\text { treatment }\end{array}$ & $\begin{array}{c}\text { After } \\
\text { captopril }\end{array}$ & $\begin{array}{c}\text { After } \\
\text { placebor }\end{array}$ \\
\hline & \multicolumn{9}{|c|}{ Systolic blood pressure $(\mathrm{mm} \mathrm{Hg}$} \\
\hline Baseline & $128(18)$ & $122(20)$ & $130(21)$ & $135(16)$ & $129(18)$ & $134(15)$ & $141(20)$ & $137(21)$ & $140(18)$ \\
\hline Immediately after exercise & $177(36)^{\star}$ & $173(28)^{\star}$ & $178(29)^{\star}$ & $185(22)^{\star}$ & $180(22)^{\star}$ & $187(25)^{\star}$ & $191(22)^{\star}$ & $185(25)^{\star}$ & $190(26)^{\star}$ \\
\hline 1 Hour after exercise & $120(17)$ & $122(17)$ & $122(15)$ & $130(18)$ & $128(20)$ & $129(16)$ & $137(21)$ & $135(19)$ & $137(17)$ \\
\hline \multirow[t]{2}{*}{24 Hours after exercise } & $127(17)$ & $128(18)$ & 131 (18) & $134(16)$ & $127(17)$ & $135(15)$ & $140(20)$ & $137(18)$ & $139(18)$ \\
\hline & \multicolumn{9}{|c|}{ Diastolic blood pressure $(\mathrm{mm} \mathrm{Hg}$ ) } \\
\hline Baseline & $83(9)$ & $80(9)$ & $82(8)$ & $86(8)$ & $82(7)$ & $85(7)$ & $90(9)$ & $86(8)$ & $88(8)$ \\
\hline Immediately after exercise & $98(12)^{\star}$ & $94(9)^{\star}$ & $99(11)^{\star}$ & $105(10)^{\star}$ & $102(9)^{*}$ & $106(12)^{\star}$ & $108(9)^{\star}$ & $104(10)^{\star}$ & $107(11)^{\star}$ \\
\hline 1 Hour after exercise & $77(8)$ & $77(7)$ & $78(8)$ & $84(6)$ & $83(9)$ & 836 & $87(9)$ & $85(7)$ & $86(9)$ \\
\hline \multirow[t]{2}{*}{24 Hours after exercise } & 818 & 786 & $80(8)$ & $87(7)$ & 837 & $82(7)$ & $88(7)$ & $88(6)$ & $88(7)$ \\
\hline & \multicolumn{9}{|c|}{ Urinary alhumin excretion rate $(\mathrm{ug} / \mathrm{min}$} \\
\hline Baseline & $8(3)$ & $9(3)$ & $8(3)$ & $16(3)$ & $15(2)$ & $16(3)$ & $48(9)$ & $46(10)$ & $48(10)$ \\
\hline Immediately after exercise & $14(4)^{\star}$ & $13(3)^{\star}$ & $15(4)^{\star}$ & $40(7)^{\star \star}$ & $28(6)^{\star \star \dagger}$ & $41(8)^{\star \star}$ & $166(24)^{\star \star}$ & $75(17)^{\star \star \ddagger}$ & $172(28)^{\star \star}$ \\
\hline 1 Hour after exercise & $21(5) \star \star$ & $17(4)^{\star \star}$ & $22(5)^{\star \star}$ & $101(20)^{\star \star}$ & $36(8) \star \star \ddagger$ & $99(19)^{\star \star}$ & $333(45)^{\star \star}$ & $107(19)^{\star \star \ddagger}$ & $345(47)^{\star \star}$ \\
\hline 24 Hours after exercise & $9(3)$ & $8(3)$ & $8(3)$ & $15(4)$ & 144 & $16(4)$ & $45(10)$ & $47(9)$ & $46(11)$ \\
\hline
\end{tabular}



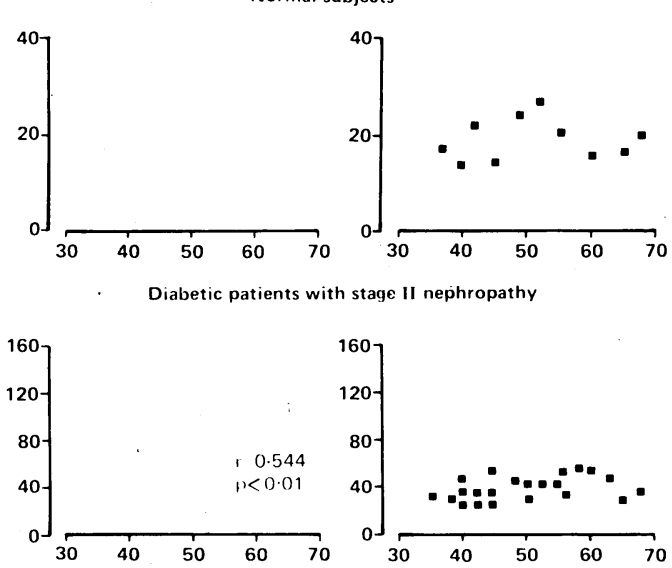

Mean urinary albumin excretion rate one hour after exercise roluted to increase in sustolic blood pressure induced by exercise in normal subjects $n=10)$ and diabetic patients with stage II nephropath $n=22$ ) and stage $I I I$ nephropathy $(n=32$ ). IV'ithout treatment, $\mathbf{0}=$ after captopril long term treatment with the selective $\beta$ blocker metoprolol. ${ }^{16-1 x}$ Hommel et al reported that urinary albumin excretion decreased when diabetic patients were given short term treatment with clonidine.$^{19}$ Long term treatment with converting enzyme inhibitors has recently been shown to induce a significant decrease in baseline urinary albumin excretion rate in normotensive diabetic patients with stage III and stage IV nephropathy."t Such inhibition could be effective in slowing the progression of diabetic nephropathy.

Our data show that short term inhibition of angiotensin converting enzyme significantly decreases exercise induced microalbuminuria in normotensive diabetic patients without affecting substantially either basal blood pressure or increases in blood pressure induced by exercise. The mechanisms by which this effect is obtained are still to be clarified. Even the mild reduction in systemic blood pressure seen when an angiotensin converting enzyme inhibitor is given can affect the urinary albumin excretion rate. The renin angiotensin system is well known, however, not only to be implicated in regulation of systemic blood pressure but also to have an important role in regulating renal microcirculation." We therefore hypothesise that the primary effect of angiotensin converting enzyme inhibition on the urinary albumin excretion rate in normotensive diabetic patients is a decrease in intraglomerular capillary pressure not dependent on variations in systemic blood pressure." Moreover, some experimental evidence suggests that inhibition of angiotensin converting enzyme can reduce microalbuminuria in diabetic patients by decreasing glomerular permeability to albumin."

No definitive conclusions can be drawn from our data, but no significant difference in increases in blood pressure was seen between diabetic and normal subjects when exercise was performed after captopril had been given. In addition, the correlation observed basally and after placebo between the increases in blood pressure and microalbuminuria induced by exercise was not found with captopril. Thus we suggest that increased excretion of albumin after exercise as well as baseline microalbuminuria in diabetic patients may be affected by angiotensin converting enzyme inhibition either through a reduction in renal intracapillary pressure not dependent on a decrease in systemic blood pressure or through a decrease in glomerular permeability to albumin. Our data clearly indicate that the decrease of urinary albumin excretion rate after exercise with captopril is independent of the baseline urinary albumin excretion rate and the peak blood pressures during exercise.

The finding that short term angiotensin converting enzyme inhibition can reduce exercise induced microalbuminuria in normotensive diabetic patients with stage II nephropathy to that of normal subjects suggests that progression of nephropathy in this early phase could also be slowed by captopril. Further long term studies on this important point are in progress. Undoubtedly these results should be interpreted with caution; firstly, we do not yet know whether all diabetics with stage II nephropathy with exercise induced microalbuminuria will develop baseline microalbuminuriat; and, secondly, it is not clear whether the reduction in microalbuminuria indicates a reduction in structural glomerular lesions.

Normalisation of albuminuria induced by exercise in diabetic patients who have stage II renal disease has been seen after continuous subcutaneous administration of insulin with portable pumps. " sation may be due to regression of structural lesions in the kidney, although the effects of strict metabolic control on urinary albumin excretion rate in type I diabetes are still controversial. ${ }^{13 \cdot 14}$

A decrease in baseline and exercise induced microalbuminuria has been reported in hypertensive diabetic patients with incipient proteinuria given
1 McCrary RF, Pitts TO, Puschett JB. Diabetic nephropathy. Natural course. survivorship and therapy. A $m$ f Nephrol 1981;1:206-18.

Andersen AR, Christansen JS, Andersen JK, Kreiner S, Deckert $T$. Dabetic nephropathy in type I (insulin-dependent) diabetes: an epidemiological study. Diuhelologia 1983;2:496-501.

3 Viberti (GC, Jarret RJ, Mahmud U, Hill RD), Argyropoulos A, Keen $\mathrm{H}$. Microalhuminuria as a predictor of clinical nephropathy in insulin dependent diabetes mellitus. Lancet 1982;i:1430-2. disease with emphasis on the stage of incipient dabetic nephropathy. Diabetes 1983:32 suppl 2i:6+-78.
+ Mogenen CF Christensen CK, Vitinghus $\mathrm{E}$ The stages in diahetic renal 
5 Marre M, Leblanc H, Suarez L, Guvenne TT, Menard J, Passa P. Converting enzyme inhibition and kidney function in normotensive diabetic patients with persistent microalbuminuria. Br.Med F 1987;294:1448-52.

6 Feldt-Rasmussen B, Mathiesen ER. Variability of urinary albumin excretion in incipient diabetic nephropathy. Diabetic Nephropathy 1984:3:101-3.

Winer BJ. Statistical analysis in experimental design. 2nd ed. New York: McGraw-Hill, 1971

8 Osterby R, Gundersen HJG, Horlyck A, Kroustrup JP, Nyberg G, Westberg G. Diabetic glomerulopathy. Structural characteristics of the early and Ged Des 1983:32

9 Koivisto VA, Huttunen NP, Vierikko P. Continuous subcutaneous insulin infusion corrects exercise-induced albuminuria in juvenile diabetes. infusion corrects exercis
$B r$ Med f 1981;282:778-9.

10 Viberti G, Pickup JC, Bilous RW, Keen H, MacKintosh D. Correction of exercise induced microalbuminuria in insulin dependent diabetes mellitus Diabetes 1981;30:818-23.

11 Jefferson JG, Greene SA, Smith MA, Smith RF, Griffin NKG, Baum JD Urine albumin to creatinine ratio-response to exercise in diabetes. Arch $D i s$ Child 1985;60:305-10.

12 Vittinghus E, Mogensen CE. Graded exercise and protein excretion in diabetic man and the effect of insulin treatment. Kidney Int 1982;21:725-9.

13 Viberti GC, Pickup JC, Jarret RJ, Keen H. Effect of control of blood glucose on urinary excretion of albumin and beta-2-microglobulin in insulin dependent diabetes. N Engl f Med 1979;302:638-41.

14 Kroc Collaborative Study Group. Blood glucose control and the evolution of diabetic retinopathy and albuminuria: a preliminary multicenter trial. NEngl F Med 1984;311:365-77.
15 Feldt-Rasmussen B, Mathiesen ER, Hegedus L, Deckert T. Kidney function during 12 months of strict metabolic control in insulin dependent diabetic patients with incipient nephropathy. $\mathcal{F}$ Clin Invest 1986;77:1925-30.

16 Mogensen CE. Long term antihypertensive treatment inhibiting progression of diabetic nephropathy. Br Med f 1982:285:685-8.

17 Christensen CK, Mogensen CE. Effect of antihypertensive treatment on progression of incipient diabetic nephropathy. Hypertension 1985:7.9-13.

Friedman PJ, Dunn PJ, Jury DR. Metoprolol and albumin excretion in diabetes Lencet 1986;ii:43.

9 Hommel E, Mathiesen E, Edsberg B, Bahnen M, Parving HH. Acute reduction of arterial blood pressure reduces albumin excretion in type I (insulin dependent) diabetic patients with incipient nephropathy. Diabsulin dependent) diabet

20 Taguma Y, Kilamoto Y, Futaki G, et al. Effect of captopril on heavy proteinuria in azotemic diabetics. N Engl F Med 1985;313:1617-20.

21 Brown JJ, Leckie BJ, Lever AF, et al. The renin angiotensin system and the regulation of the circulation. In: Robertson JIS, ed. Handbook of hypertension. Vol I. Clinical aspects of essential hypertension. Amsterdam: Elsevier, 1983:278-323.

22 Hanson $L$. The therapeutic use of angiotensin converting enzyme inhibitors. In: Robertson JIS, ed. The renin angiotensin system, Module 8. London: Gower Medical, 1985:141-6.

23 Zatz R, Dunn BR, Meyer TW, Anderson S, Rennke HG, Brenner BM. Prevention of diabetic glomerulopathy by pharmacological amelioration of glomerular capillary hypertension. F Clin Invest 1986;77:1925-30.

(Accepted 28 October 1988)
Gynaecological Oncology Unit, King George V Memorial Hospital, Royal Prince Alfred Hospital, Camperdown, New South Wales 2050, Australia P M Elliott, FRACOG, surgeon M H N Tattersall, FRACP, medical oncologist

M Coppleson, FRACOG, surgeon

P Russell, FRCPA, pathologist

F Wong, MRCOG, fellow

A S Coates, FRACP, medical oncologist

H J Solomon, FRACOG, surgeon

P M Bannatyne, FRCPA, pathologist

K H Atkinson, FRACOG, surgeon

J C Murray, FRACOG, surgeon

Correspondence to: $\mathrm{Mr}$ Elliott.

\title{
Changing character of cervical cancer in young women
}

\author{
P M Elliott, M H N Tattersall, M Coppleson, P Russell, F Wong, A S Coates, H J Solomon, \\ P M Bannatyne, K H Atkinson, J C Murray
}

\section{Abstract}

To examine the hypothesis that the pattern of cervical cancer is changing data on women presenting with the disease over 34 years were studied retrospectively. During 1953-86, 2628 women with cervical cancer were referred to a large tertiary referral hospital in Sydney; 418 were aged 35 or less. During the period of review the proportion of young women with the disease increased from under $9 \%$ in the 1950 s and 1960 s to about $25 \%$ in the 1970 s and 1980s; a similar but less pronounced trend was apparent for the whole of New South Wales in the 1970s and 1980s. The prevalence of less common morphological types of cervical cancer increased throughout the period, particularly in the young. Pelvic lymph node metastases were identified in younger patients with stage Ib and IIa tumours more commonly in the later years of the study, suggesting that the disease was becoming more severe. Overall rates of recurrence improved over time, but an apparent increase in early recurrences was observed in young patients with Ib and IIa tumours and without nodal disease. The results suggest that the clinical and pathological behaviour of cervical cancer changed over the period of review.

\section{Introduction}

For some years gynaecologists managing cervical cancer have thought that the pattern of the disease has been changing. The use of Papanicolaou smears had led to earlier detection of clinical and preclinical lesions so that fewer patients were presenting with locally advanced disease. More recently, however, the disease has become more common and apparently more severe among young women. Epidemiological reports in the past 15 years have mostly confirmed this impression and indicated that cervical cancer is now both more common and associated with an increasing mortality in younger women. ${ }^{1 \cdot 17}$ The proportion of cases of cervical cancer in young women varies in different reports, from $7-14 \%$ in Scandinavia to up to $25 \%$ in a small series from the United States. ${ }^{18-20}$ These variations presumably reflect differing referral, demographic, geographic, racial, and social patterns.

To check the validity of theories on the increase in cervical cancer in younger women we analysed the patterns of cervical cancer in patients admitted to a large tertiary referral hospital in Sydney during 1953-86.

\section{Patients and methods}

The study comprised 2628 patients with cervical cancer admitted to King George V Hospital, Sydney, for part or all of their primary treatment during 1953-86. The histological characteristics of the tumours were reviewed by two gynaecological pathologists (PR and PB). Tumours were classified into the following types: adenocarcinomas and keratinising, non-keratinising, small cell squamous, adenosquamous, undifferentiated small cell (oat cell), adenoid cystic or adenoid basal, and unclassified carcinomas.

Radical hysterectomy with pelvic lymphadenectomy was the preferred treatment for stage Ib and IIa disease and some early stage IIb tumours. During 1953-69, surgery was usually preceded by intracavitary radium treatment. Those women with node metastases generally received postoperative external pelvic radiotherapy. From the early 1970s all lymphoid tissue was embedded in paraffin blocks and step sectioned six times to permit improved detection of microscopic metastases. Radical pelvic irradiation (external and intracavitary) was generally used for stage IIb to stage IV tumours.

Preclinical cancers were defined as those requiring colposcopically directed punch or cone biopsy to establish the diagnosis and those clinically unrecognised or unsuspected lesions found on routine histological examination of uteruses or cervices removed for supposed benign disease. These preclinical cancers were subdivided into a microinvasive subgroup, in which the tumour had penetrated less than $5 \mathrm{~mm}$ into the stroma measured from the surface of the cervical epithelium, and an occult subgroup, in which invasion exceeded this limit, irrespective of the volume of the 